\title{
Primary Hepatic Burkitt's Lymphoma in an Immunocompetent Patient: Case Report and Review of the Literature
}

\author{
Semra Paydas ${ }^{1 *}$, Haluk Demiryurek ${ }^{2}$, Melek Ergin ${ }^{3}$, Arbil Acikalin ${ }^{3}$ \\ ${ }^{1}$ Department of Oncology, Curkurova University, Adana, Turkey; ${ }^{2}$ Department of General Surgery, Curkurova University, Adana, \\ Turkey; ${ }^{3}$ Department of Pathology, Curkurova University, Adana, Turkey. \\ Email: sepay@cu.edu.tr
}

Received December $25^{\text {th }}, 2012$; revised January $27^{\text {th }}, 2013$; accepted February $8^{\text {th }}, 2013$

\begin{abstract}
Primary hepatic Burkitt's lymphoma (PHBL) is rarely seen in adults. Here we reported a case presenting with hepatomegaly and diagnosed as PHBL and also reviewed the literature.
\end{abstract}

Keywords: Primary Hepatic Burkitt's Lymphoma; EBV; Immunodeficiency; Immunocompetent

\section{Introduction}

Primary hepatic lymphoma (PHL) is rare in adults. Diagnosis is not easy in the majority of these cases. Generally there is an important delay in the diagnosis of this entity and in some cases PHL can be diagnosed at autopsy. This is a disease of middle aged men and median age is 50 years. The most common presenting symptoms are abdominal pain, fatigue and constitutional symptoms. Physical examination shows hepatomegaly and jaundice in the majority of the cases $[1,2]$.

Burkitt's lymphoma (BL) is the most common subtype of non-Hodgkin's lymphoma (NHL) in children and accounts about $50 \%$ of the cases, however in adults it is seen in $2 \%-3 \%$ of the cases with NHL. PHBL in adults is seen very rare and most of the cases have been reported in cases with human immunodeficiency virus (HIV) infection. Here we reported a PHBL in an immunocompetent woman and reviewed the literature.

\section{Case Report}

A 31-year-old woman admitted to the Department of Surgery due to right upper quadrant pain radiating to the right shoulder. She had weight loss in recent weeks. Physical examination showed pallor, hepatomegaly and tenderness on the right upper quadrant.

Past medical history of the patient was unremarkable.

Patient was evaluated for hepatomegaly. Ultrasonographically there was mass lesion with mixed echo pattern in the liver. Abdominal magnetic resonance imaging

"Corresponding author.
(MRI) showed multiloculated cystic lesions with solid components filling the left and right anterior segments of the liver.The lesion was measured as $20 \times 10 \mathrm{~cm}$. diameter. PET CT showed a giant mass with $16 \mathrm{~cm}$ diameter in the left lobe and caudate lobe of the liver (SUV max 32) (Figure 1). Laboratory: Hb $10.1 \mathrm{~g} / \mathrm{dl}$, Hct: $31.7 \%$ WBC count: $14.1 \times 10^{9} / \mathrm{L}$, platelet count: $865 \times 10^{9} / \mathrm{L}$, total protein/albumin: $6 / 3.4 \mathrm{~g} / \mathrm{dl}$, total/direct bilirubine: $0.92 /$ $0.28 \mathrm{mg} / \mathrm{dl}$, AST/ALT: 65/65 U, Alkaline phosphatase: $369 \mathrm{U}(\mathrm{N}: 5-240)$, glucose: $118 \mathrm{mg} / \mathrm{dl}, \mathrm{Ca}: 8.6 \mathrm{mg} / \mathrm{dl}$, $\mathrm{Na} / \mathrm{K}: 142 / 3.6 \mathrm{mEq} / \mathrm{L}$. Liver biopsy was done but tissue sample was non-diagnostic and reported as "disseminated necrotic-inflammatory focuses in the liver". The differentiation could not be made between inflammation and neoplasia in biopsy sample. Repeated MRI showed
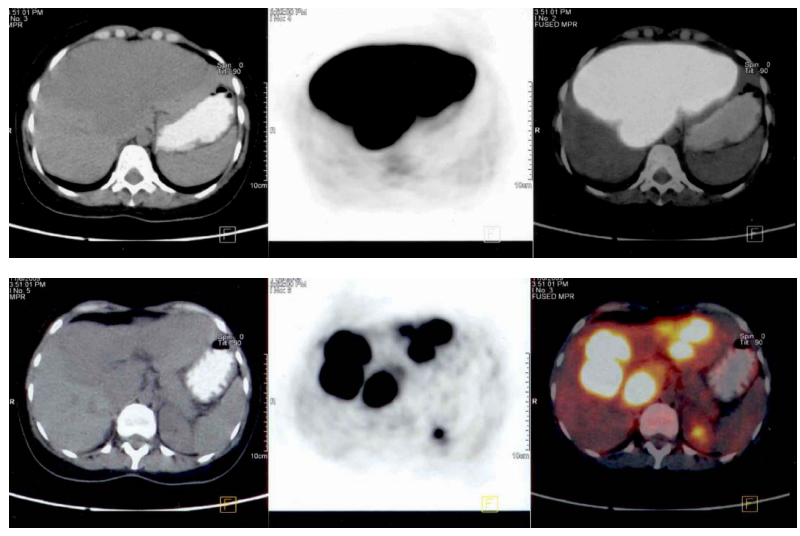

Figure 1. PET CT showing a giant mass with $16 \mathrm{~cm}$ diameter (SUV max 32) in the left lobe and caudate lobe of the liver. 
progression in the mass and laparotomy was done. Complete tumor resection with left hepatectomy and caudate lobectomy were peformed (Figure 2). Histopathological examination of this specimen was compatible with BL. In resection specimen, there was diffuse infiltration of medium to large sized cells with few admixed small lymphocytes in the liver. Many mitotic figures and starry sky macrophages were observed. Immunohystochemically (Figure 3); CD20 was found to be positive, CD3 was negative and proliferation index by ki-67 was almost $100 \%$. EBER-RNA by in situ hybridisation was found to be negative.

Patient was diagnosed as BL with high risk fetaures. Four courses of alternating CODOX-M $\times$ IVAC (CODOX: cyclophosphamide $800 \mathrm{mg} / \mathrm{m}^{2}$ IV D1, $200 \mathrm{mg} / \mathrm{m}^{2}$ D2-5, doxorubicine $40 \mathrm{mg} / \mathrm{m}^{2}$ IV D1, vincristine $1.5 \mathrm{mg} / \mathrm{m}^{2}$ IV $\mathrm{D} 1+8$, cytosine arabinoside $70 \mathrm{mg}$ intrathecal $\mathrm{D} 1+3$, methotrexate $1200 \mathrm{mg} / \mathrm{m}^{2}$ IV D10 one hour infusion and $5500 \mathrm{mg} / \mathrm{m}^{2}$ D10 23 hours infusion with leucovorine rescue. IVAC: etoposide $60 \mathrm{mg} / \mathrm{m}^{2}$ IV D1-5, ifosfamide $1500 \mathrm{mg} / \mathrm{m}^{2} \mathrm{D} 1-5$, cytosine arabinoside $2900 \mathrm{mg} / \mathrm{m}^{2}$ D1-4, methotrexate $12 \mathrm{mg} \mathrm{D}$ intrathecal) regimen was given. Although septic episodes developed during chemotherapy, complete remission was found at control PET $\mathrm{CT}$ and she is in good health after three years. Her liver

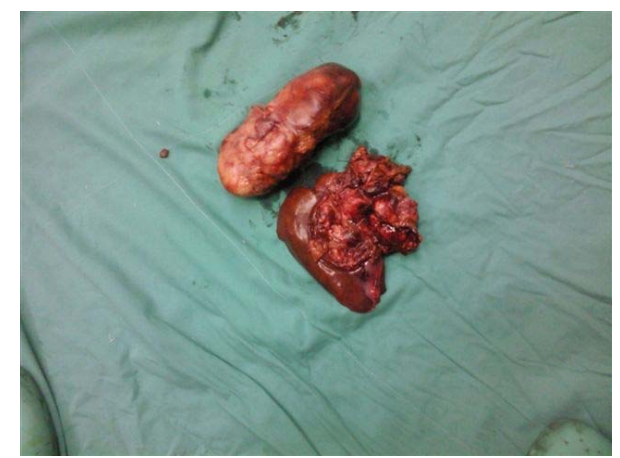

Figure 2. Resection material taken from left hepatectomy and caudate lobectomy.

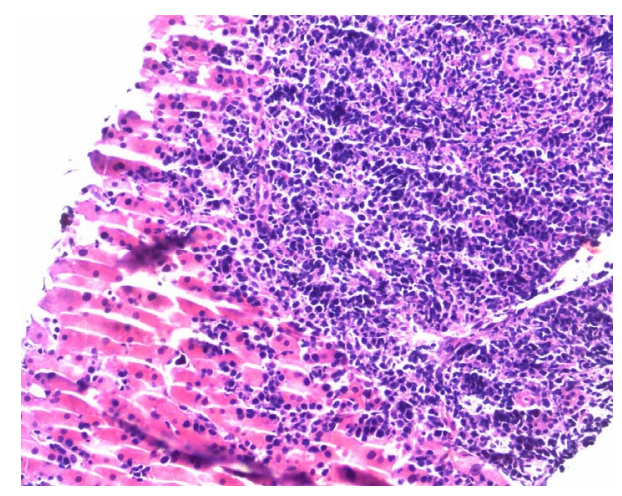

Figure 3. Diffuse infiltration of medium to large sized cells with few admixed small lymphocytes in the liver. Many mitotic figures and focal starry sky macrophages are seen. function tests are normal and she gained 10 kilograms.

\section{Discussion}

PHL is a rare entity accounting $0.4 \%$ of all extranodal lymphomas [3]. This rare disease has some interesting points both in diagnosis and management [2]. Classically PHL presents as solitary nodule or multifocal hepatic masses. It has been suggested that, PHL must be considered in cases with primary hepatic tumor in an immunocompromised case and in the absence of elevation of the serum tumor markers such as alpha feto protein (AFP) and carcinoembryonic antigen (CEA). Additionally, this entity must be considered in a case with hepatic mass or masses in the peresence of increased serum LDH, liver enzymes and beta 2 microglobulin activity, [2,4]. Median age is 50 [2]. It has been reported that hepatic lymphoma is the second most common neoplasia after Kaposi Sarcoma in cases with HIV infection [5]. Right upper quadrant pain and hepatomegaly are the two most frequently seen symptom and finding, respectively. Acute liver failure may be the presenting feature and diagnosis is generally confirmed at autopsy in these cases. Severe hypoglycemia and lactic acidosis may be seen and are due to the diffuse liver infiltration [6,7]. Generally these cases have unfavorable histologic subtypes and majority have B cell phenotype [2,4,5,7-9]. Radiologic images are variable, PHL may be seen as the single lesion or small innumerable intrahepatic masses or diffuse hepatic infiltration $[2,5]$.

PHBL accounts for about 3\% of the PHLs in adults $[4,5,10,11]$. Symptoms of the cases with PHBL are abdominal pain, distension, nausea, vomiting, fever, weight loss, jaundice, diarrhea and encephalopathy in some cases. Imaging criteria are not specific as mentioned in PHL and similar imaging features have been reported. Definitive diagnosis requires liver biopsy. However percutaneous liver biopsy may be non diagnostic in some cases as seen in our case [12-14]. EBV is detected in less than $20 \%$ of the cases with sporadic BL, so some cases with PHBL have EBV. AIDS related lymphomas include essentially primary CNS lymphomas, primary effusion lymphomas and plasmablastic lymphomas and also PHBL. Most of the AIDS related lymphomas belong to one of three categories of high grade B cell lymphomas, $\mathrm{BL}$, centroblastic lymphomas and immunoblastic lymphomas [15]. HCV and/or HBV may be seen in some cases [5,14,16-18].

In adults PHBL has been reported in 7 cases. Five of these cases died in a short term after diagnosis. Table 1 shows some clinical presentation, laboratory findings and imaging properties of these cases. As seen in table, age range was between 20 and 82 the most frequent symptoms were abdominal pain. HIV was found to be positive in 3 of them and LDH was very high in all of 
Table 1. Primary hepatic Burkitt’s lymphoma cases-literature review.

\begin{tabular}{|c|c|c|c|c|c|c|c|c|c|c|c|c|c|c|c|}
\hline Number & Age & Gender & Presentation & $\mathrm{HCV}$ & $\mathrm{HBV}$ & EBV & HIV & LDH & AST & ALT & CRP & Lesion & Chemotherapy & Survival & Ref \\
\hline 1 & 75 & M & $\begin{array}{l}\text { Hepatic tumor, } \\
\text { ascites }\end{array}$ & + & NA & - & - & $\mathrm{H}$ & $\mathrm{H}$ & $\mathrm{H}$ & $\mathrm{H}$ & Solitary & CHOP & 8 days & [16] \\
\hline 2 & 32 & M & $\begin{array}{l}\text { B symptom, } \\
\text { hepatomegaly, } \\
\text { jaundice }\end{array}$ & - & + & + & + & & $\mathrm{H}$ & $\mathrm{H}$ & & $\begin{array}{c}\text { Multiple } \\
\text { innumerable }\end{array}$ & m BACOD & 15 days & {$[5]$} \\
\hline 3 & 47 & M & & NA & & & & & & & & & Combined CT & 2 months & {$[4]$} \\
\hline 4 & 82 & $\mathrm{~F}$ & $\begin{array}{l}\text { Abdominal } \\
\text { distension }\end{array}$ & NA & - & NA & - & $\mathrm{H}$ & $\mathrm{H}$ & $\mathrm{H}$ & & $\begin{array}{l}\text { Multiple } \\
\text { hypodense }\end{array}$ & $\mathrm{COPP} \times 3$ & 4 months & [17] \\
\hline 5 & 20 & M & $\begin{array}{l}\text { Right upper } \\
\text { quadrant pain }\end{array}$ & - & + & & - & $\mathrm{H}$ & & $\mathrm{H}$ & & Multiple & $\begin{array}{l}\text { CHOP HD Mtx } \\
\text { IT Mtx }\end{array}$ & 1 year+ & [14] \\
\hline 6 & 40 & $\mathrm{~F}$ & $\begin{array}{l}\text { Weight loss, } \\
\text { generalized } \\
\text { edema }\end{array}$ & & & & + & $\mathrm{H}$ & & & & $\begin{array}{c}\text { Multiple } \\
\text { hypovascular }\end{array}$ & $\mathrm{CHO}$ & Exitus & [12] \\
\hline 7 & 60 & M & $\begin{array}{l}\text { ALF, massive } \\
\text { HM, abdominal } \\
\text { tenderness }\end{array}$ & - & - & + & + & $\mathrm{H}$ & $\mathrm{H}$ & $\mathrm{H}$ & & $\begin{array}{c}\text { Multiple } \\
\text { innumerable }\end{array}$ & $\begin{array}{c}\text { Ara-C } \\
\text { Rituximab } \\
\text { Dexamethason }\end{array}$ & $\begin{array}{c}10 \\
\text { months+ }\end{array}$ & [13] \\
\hline 8 & 66 & $\mathrm{~F}$ & ALF & & & & & & & & & & & 2 days & {$[6]$} \\
\hline $\begin{array}{c}9 \\
\text { presented } \\
\text { case }\end{array}$ & 32 & $\mathrm{~F}$ & $\begin{array}{l}\text { Right upper } \\
\text { quadrant pain }\end{array}$ & - & - & - & - & $\mathrm{H}$ & $\mathrm{H}$ & $\mathrm{H}$ & & Multiple & $\begin{array}{l}\text { Rituximab + } \\
\text { CODOX-M } \\
\quad \text { IVAC }\end{array}$ & $\begin{array}{c}10 \\
\text { months }+\end{array}$ & \\
\hline
\end{tabular}

Abbreviations: F: female; M: male; H: high; NA: not assessed; EBV: Epstein Barr virus; HIV: human immunodeficiency virus; CHOP: cyclophosphamidedoxorubicine-vincristine-prednisolone; m BACOD: methotrexate, bleomycin, doxorubicin, vincrisitin, dexamethason; CT: chemotherapy; COPP: cyclophosphamide-doxorubicine-procarbazin-prednisolone; HD: high dose; Mtx: methotrexate; IT: intrathecal; Ara-C: cytosine arabinoside; CODOX-M: cyclophosphamide-doxorubicin-vincristine-methotrexate-ifosfamide-cytosine arabinoside.

them and this is an important marker for aggressive behavior and high tumor burden $[5,12,13]$. All the cases, except one, had multiple hepatic lesions. Combination chemotherapy was given to all cases but only 2 cases lived 10 and $12+$ months. The critical points are early diagnosis of this entity and also the treatment with aggressive multiagent chemotherapy like CODOX-M $\times$ IVAC, Hyper CVAD MTX as soon as possible. Very high cure rates and long term survial are possible with intensive chemotherapy regimens.

Our case has some interesting properties; she was immunocompetent young female, initial biopsy samples did not reveal the diagnosis and she required operative biopsy. Percutaneous liver biopsy was nondiagnostic due to severe necrosis. Complete remission and relatively long term remission was achieved by surgery and agressive chemotherapy. The place of surgery in the management of this disease is not clear but aggressive combination chemotherapy is necessary.

\section{REFERENCES}

[1] K. Lei, "Primary Non-Hodgkin's Lymphoma of the Liver," Leuk Lymphoma, 1998, Vol. 29, pp. 293-299. doi:10.3109/10428199809068566

[2] R. D. Page, J. E. Romaguera, B. Osborne, L. J. Medeiros, J. Rodriguez and F. Cabanillas, "Primary Hepatic Lymphoma," Cancer, Vol. 92, No. 8, 2001, pp. 2023-2029. doi:10.1002/1097-0142(20011015)92:8<2023::AID-CNC

\section{$\underline{\mathrm{R} 1540>3.0 . \mathrm{CO} ; 2-\mathrm{B}}$}

[3] C. Freeman, J. W. Berg and S. J. Cutler, "Occurrence and Prognosis of Extranodal Lymphomas," Cancer, Vol. 29, 1972, pp. 252-260.

doi:10.1002/1097-0142(197201)29:1<252::AID-CNCR28 20290138>3.0.CO;2-\#

[4] J. Y. Scoazec, C. Degott, N. Brousse, J. Barge, G. Molas, F. Potet and J. P. Benhamou, 'Non-Hodgkin's Lymphoma Presenting as a Primary Tumor of the Liver: Presentation, Diagnosis and Outcome in Eight Patients," Hepatology, Vol. 13, No. 5, 1991, pp. 870-875.

doi:10.1002/hep.1840130512

[5] S. B. Mossad, J. W. Tomford, R. K. Avery, M. A. Hussein and K. W. Vaughn, "Isolated Primary Hepatic Lymphoma in a Patient with Acquired İmmunodeficiency Syndrome," International Journal of Infectious Diseases, Vol. 4, No. 1, 2000, pp. 57-58. doi:10.1016/S1201-9712(00)90069-9

[6] E. S. Zafrani, B. Leclercq, J. P. Vernant, Y. Pinaudeau, G. Chomette and D. Dhumeaux, "Massive Blastic İnfiltration of the Liver: A Cause of Fulminant Hepatic Failure," Hepatology, Vol. 3, No. 3, 1983, pp. 428-432. doi:10.1002/hep. 1840030324

[7] T. M. Shehab, M. S. Kaminski and A. S. F. Lok, "Acute Liver Failure Due to Hepatic İnvolvement by Hematologic Malignancy," Digestive Diseases and Sciences, Vol. 42, No. 7, 1997, pp. 1400-1405. doi:10.1023/A:1018889904839

[8] V. S. Avlonitis and D. Linos, "Primary Hepatic Lymphoma: A Review," European Journal of Surgery, Vol. 165, 1999, pp. 725-729. doi:10.1080/11024159950189474 
[9] K. Azasa, K. Mishima and M. Ohsawa, "Primary Malignant Lymphoa of the Liver," Leuk Lymphoma, Vol. 19, 1993, pp. 353-357. doi:10.3109/10428199309148560

[10] Y. L. Wan, W. J. Chen, S. C. Huang, T. Y. Lee and C. C. Tsai, "Solitary Hepatic Burkitt Lymphoma Presenting as Acute Pancreatitis," Pediatric Radiology, Vol. 18, No. 2, 1988, p.160. doi:10.1007/BF02387562

[11] G. Ramos, M. Murao, B. M. De Oliveira, L. P. F. De Castro and M. B. Viana, "Primary Hepatic Non-Hodgkin's Lymphoma in Children: A Case Report and Review of the Literature," Medical and Pediatric Oncology, Vol. 28, No. 5, 1997, pp. 370-372. doi:10.1002/(SICI)1096-911X(199705)28:5<370::AID-M PO9>3.0.CO;2-E

[12] S. L. Jacobs and A. Rozenblit, "HIV-Associated Hypervascular Primary Burkitt's Lymphoma of the Liver," Clinical Radiology, Vol. 61, No. 5, 2006, pp. 453-455. doi:10.1016/j.crad.2005.12.007

[13] W. E. Mattar, B. K. Alex and A. H. Sherker, "Primary Hepatic Burkitt Lymphoma Presenting with Acute Liver Failure," Journal of Gastrointestinal Cancer, 2010.

[14] S. H. Lee, H. J. Kim, J. S. Mun, H. C. Oh, H. W. Lee, C.

\section{Abbreviations}

BL: Burkitt's lymphoma;

PHL: Primary hepatic lymphoma;

PHBL: Primary hepatic Burkitt's lymphoma;

NHL: Non-Hodgkin's lymphoma;

HCV: Hepatitis C virus;

HBV: Hepatitis B virus;
H. Choi, J. W. Kim, J. H. Do, J. G. Kim, S. K. Chang and M. K. Kim, "A Case of Primary Hepatic Burkitt's Lymphoma," Korean Journal of Gastroenterology, Vol. 51, 2008, pp. 259-264.

[15] A. Carbone, "Emerging Pathways in the Development of AIDS-Related Lymphoma," Lancet Oncology, Vol. 4, No. 1, 2003, pp. 22-29. doi:10.1016/S1470-2045(03)00957-4

[16] J. Kuroda, A. Omoto, H. Fujiki, K. Okugawa, H. Tamai, H. Yamagishi, Y. Kobayashi and T. Yoshikawa, "Primary Hepatic Burkitt's Lymphoma with Chronic Hepatitis C," Acta Haematologica, Vol. 105, 2001, pp. 237-240. doi:10.1159/000046571

[17] P. Souto, J. M. Romãozinho, P. Figueiredo, M. Ferreira, I. Sousa, E. Camacho, A. Donato and D. Freitas, "Severe Acute Liver Failure as the Initial Manifestation of Haematological Malignancy," European Journal of Gastroenterology \& Hepatology, Vol. 9, No. 11, 1997, pp. 11131115. doi:10.1097/00042737-199711000-00016

[18] C. S. Chim, C. Choy, G. C. Ool and R. Liang, "Primary Hepatic Lymphoma," Leuk Lymphoma, Vol. 40, No. 5-6, 2001, pp. 667-670. doi:10.3109/10428190109097665

HIV: Human immunodeficiency virus;

MRI: Magnetic resonance imaging;

AFP: Alpha feto protein;

CEA: Carcinoembryonic antigen;

PET CT: Positron emission tomography;

CNS: Central nervous system;

IV: Intravenous. 